\title{
RACIAL DISCRIMINATION IN PROFESSIONAL BASKETBALL: EVIDENCE FROM NIELSEN RATINGS
}

\author{
MARK T. KANAZAWA and JONAS P. FUNK*
}

\begin{abstract}
Using data on Nielsen ratings for locally televised NBA basketball games, we find strong evidence that viewership increases when there is greater participation by white players. This finding controls for a wide variety of other factors that could systematically affect Nielsen ratings, and signifies the presence of customer discrimination in the market for NBA players. We also find that higher Nielsen ratings allow NBA teams to realize greater advertising revenues, meaning that the marginal revenue product of white players exceeds that of comparable black players. This factor explains much of the race-based salary gap that exists in professional basketball. (JEL J4, J7)
\end{abstract}

\section{INTRODUCTION}

Are black professional athletes subject to racial discrimination? This question has received an enormous amount of popular and scholarly attention. However, despite numerous economic studies that have attempted to provide an answer, the evidence remains mixed and inconclusive. In this study, we examine whether patterns of television viewing are systematically correlated with the racial composition of teams in the National Basketball Association (NBA). To our knowledge, the television viewing habits of sports consumers, as reflected in Nielsen ratings, have not been studied by economists looking for evidence of racial discrimination in professional sports.

The next section examines an important subset of the literature on racial discrimination in sports: discrimination by sports consumers or more colloquially, fans. Section III describes our data set, including the main focus of our study: Nielsen ratings for local, non-cable NBA basketball games. Section IV

\footnotetext{
*We wish to thank Bill Boal, Andy Hanssen, seminar participants at Montana State University, and two anonymous referees for helpful comments. We are grateful to Nielsen Media Research for providing the Nielsen data, and to Carleton College for funding purchase of the data for this project.

Kanazawa: Professor of Economics, Carleton College, 1 North College St., Northfield, MN 55057. Phone 1-507-646-4106, Fax 1-507-646-4044, E-mail mkanazaw@carleton.edu

Funk: Financial Analyst, Mediaplex, 177 Steuart St, San Francisco, CA 94109. Phone 1-415-808-1983, Fax 1-415-808-1901, E-mail jfunk@mediaplex.com
}

reports the main results of the econometric analysis. The principal finding is that the size of television audiences viewing NBA games is positively correlated with increasing participation by white players in NBA games. This result indicates the presence of consumer discrimination in the market for NBA players. Section V reports the results of further analysis to quantify the relationship between commercial advertising revenues and the number of viewers watching NBA games. We find that commercial advertisers pay more for commercial slots when more viewers are tuned in, indicating that white players provide teams with extra advertising revenues. Our estimated revenue differential is comparable in magnitude to a white-black salary differential documented by several existing studies of the NBA, suggesting that advertising revenues may explain much of the salary differential. Section VI summarizes our findings.

\section{WHAT DO WE KNOW ABOUT CONSUMER DISCRIMINATION IN PRO SPORTS?}

A number of economic studies have examined whether consumers of professional sporting events discriminate against black athletes. Three main approaches have been pursued, yielding mixed results. One approach examines whether fans are willing to pay more for sports memorabilia

1. Discrimination can take other forms as well, including discrimination by team owners, or other athletes. See, for example, Becker (1971). We do not consider these other forms of discrimination here. 
of white players than of non-white players, an approach pursued in several studies of baseball. Nardinelli and Simon (1990) found significantly lower demand for baseball memorabilia of non-white (i.e., black or Hispanic) players, as reflected in the prices of baseball cards. This result was partly corroborated by Andersen and Lacroix (1991), who found lower prices for the baseball cards of blacks, though not for Hispanics. On the other hand, Gabriel, Johnson, and Stanton (1995) uncovered little evidence of price differentials in the baseball cards of the different racial groups.

A second approach has been to examine voting by fans for all-star teams. Hanssen and Anderson (1999), for example, have applied this approach to major league baseball. They discovered significant voting discrimination against black players during the 1970 s which has, however, steadily decreased over time. They find little evidence of discrimination currently against blacks. To our knowledge, this approach has not been applied to other professional sports.

A third approach examines whether the racial composition of a team influences fans' willingness to attend sporting events. Again the evidence is mixed. Schollaert and Smith (1987) found that the racial composition of an NBA team had an insignificant effect on attendance at games. Similarly, Brown, Spiro, and Keenan (1991) found attendance unaffected by the amount of time played by black players. On the other hand, Kahn and Sherer (1988) found attendance significantly higher for NBA teams fielding more white players. ${ }^{2}$

Fan interest in and loyalty to a professional team may, of course, be manifested in other ways. Many professional games are broadcast on local and national television, and fans may make viewing decisions partly on the basis of the racial composition of a team, as with attendance. Indeed, team racial composition may affect television viewing more strongly than attendance, because fans actually attending a game are likely to have greater knowledge and more intense interest in the sport than typical television viewers. They may therefore be less likely to base decisions to attend on factors more

2. For baseball, Kahn (1991) concluded that there is no recent evidence that black players affect either team revenues or attendance. peripheral to the outcome of a game, such as team racial composition.

\section{DATA}

Our study uses data on television viewing of local non-cable broadcasts of NBA basketball games during the 1996-97 basketball season, provided by the Nielsen Media Research company. Because we will be using team winning percentages to control for team performance, the study is confined to games later in the season, after a sufficient number of games has been played for winning percentage to accurately reflect team performance. Specifically, we use games played in the second half of the 1996-97 season, during the months of January and February 1997. This data set includes 258 local, non-cable games for most NBA teams, and comprises the vast majority of non-cable NBA games televised locally during this period. ${ }^{3}$ For our measure of the size of the audience watching a basketball game, we use the so-called Nielsen rating $(R A T I N G)$. The Nielsen rating is defined as the percentage of the total number of households with televisions in a given ratings area that are actually tuned in to a particular show.

Nielsen ratings for local programming are based on samples of households taken from a ratings area. Since we will use ratings to draw inferences about the larger population of viewers, the question arises of how accurately they reflect the viewing habits of the larger population. The answer seems to be: not perfectly. ${ }^{4}$ However, many of the more obvious possible sources of bias are mitigated in construction of the sample. Data on viewing patterns are compiled from electronic meters that record which channels are being watched and when, and demographic information is provided by diaries kept by members of the household for selected periods. ${ }^{5}$ These data

3. We exclude games played by the Philadelphia $76 \mathrm{ers}$, whose local games were broadcast only on cable television, and games played by the Vancouver Grizzlies and Toronto Raptors, for which no local market data on television viewing were collected. See Nielsen Media Research, NBA Sport Reference Set.

4. One criticism of Nielsen ratings relevant to this study is that they do not reflect viewing outside of the home, such as in bars and college dormitories, where the incidence of sports viewing may be higher. It is difficult to know how much bias this factor introduces.

5. The procedures for constructing Nielsen ratings for local and national programming differ in certain 
are cross-checked using comparisons with electronic records, telephone surveys, and follow-up research. As part of the verification process, attempts are made to align the demographic makeup of the sample with census data so that certain demographic groups, such as blacks or the elderly, are systematically neither under- nor overrepresented. ${ }^{6}$ This is important, for example, because the amount of time required to maintain the diaries implies that ratings may overrepresent demographic groups that have lower opportunity costs of time, such as the elderly.

To investigate the existence of discrimination by viewers, we created measures of team racial composition based both upon the presence of white players on team rosters and actual white playing time. Since basketball fans may respond to white players both on the local and opposing teams, we created race composition measures for both teams. WHPLAYLOC and WHPLAYOPP are defined as the number of white players on the local and opposing team's rosters respectively. WHMINLOC and WHMINOPP are defined as the percentage of the total minutes of playing time contributed by white players on the local and opposing teams respectively. ${ }^{7}$ The latter measures control for the possibility that white stars may have a greater effect on television viewing than marginal white players. Since we have no strong prior beliefs that simply having white players on a roster will influence viewing habits any more or less strongly than actual white playing time, we will examine the effect of both factors. ${ }^{8}$

respects. Ratings for national programming are based on larger samples and the recording of shows viewed by household members is done electronically. See Nielsen Media Research Web site.

6. Perhaps most relevant to this research, Nielsen Media Research provides evidence that their samples are not unrepresentative on the basis of race. See Nielsen Media Research Web site.

7. That is, for 48-minute basketball games involving five players, there are 240 total minutes played in a game. WHMINLOC and WHMINOPP are each simply minutes contributed by white players for each team divided by 240 .

8. One might wonder why the mere presence of white players on a team's roster would increase the number of viewers. In his popular book The Breaks of the Game, David Halberstam (1981, 4, 21) suggests that during the $1970 \mathrm{~s}$, teams were highly conscious of fan demand for white players, even marginal ones. We treat it as an open question whether such a phenomenon persists currently.
In order to isolate the effect of the racial composition of a team, we must control for other factors that could affect the size of the viewing audience. Perhaps most obvious are the quality of the team and the quality of its opponent. All else equal, more viewers will watch when the team is better and when its opponent is better. WIN\%LOC and $W I N \% O P P$ are the game-day winning percentages of the local team and its opponent, respectively. ${ }^{9}$ One might also expect viewer interest in the fortunes of a team to be higher when a team has readily-identifiable players with recognized star quality. To control for this possibility, we constructed the variable ALISTARS, which is defined as the number of players on the team who were named to the NBA all-star team in the previous season..$^{10}$

Some studies suggest that the racial composition of the metropolitan area may influence the demand for professional basketball games. For example, Noll (1974) discovered a negative correlation between attendance at professional basketball games and the percentage of the local metropolitan area which was black. ${ }^{11}$ This result has been corroborated by Kahn and Sherer (1988). To control for the racial composition of the fan base, we created the variable WHITEFANS, defined as white population as a percentage of total population in the standard metropolitan area. In our estimations, we will also control for the size of the local metropolitan viewing market using the variable HOUSEHOLDS, defined as the total number of households in the viewing market.

In addition, certain other factors such as the availability of substitutes and the timing of broadcasts may affect viewer interest in televised basketball games. For one thing, the presence of other professional sports franchises in the area may affect viewer interest in professional basketball, all else equal, in two conflicting ways. On the one hand, the presence of other professional franchises may reduce viewer interest in basketball by dividing fan loyalties among a greater number of

9. To be clear, "local" team is not the same thing as "home" team, since some of the televised games were away games.

10. Studies of attendance at NBA games have used similar measures of star players. See, for example, Kahn and Sherer (1988) and Burdekin and Idson (1991).

11. Noll (1974) also derived a similar finding for major league baseball. 
teams. On the other hand, a greater number of other professional franchises may reflect greater local demand for sports in general, which would tend to increase basketball viewing. To control for these factors, we created the variable PROTEAMS, defined as the number of major professional sports franchises (i.e., baseball, basketball, football, and ice hockey) in the viewing market.

In addition, a number of factors relating to timing may affect viewing of basketball games. We might expect, for example, the demand for games played on weekends to exceed the demand for weekday games, because of lower opportunity costs. To control for this time-of-week effect, we created the dummy variable WEEKEND, which equals one when the game was broadcast on Saturday or Sunday and zero otherwise. Viewership may also vary by the time of day, since games broadcast in the early- to midevening face stiffer competition from alternative programming. To control for this effect, we created the dummy variable PRIMETIME, which equals one when the broadcast commenced between 6:30 and 9:00 in the evening and zero otherwise. Finally, games may enjoy higher ratings due to viewer spillover when preceded by shows enjoying larger viewership. To allow for this possibility, we constructed the variable $L E A D I N$, defined as the Nielsen rating of the show televised immediately preceding the game.

Summary statistics for the explanatory variables are provided in Table 1 . Table 1 indicates that there were on average 2.4 white players on each NBA team, or about $17 \%$ of each team's roster (based on an average team roster of 14 players), who played about $17 \%$ of total team minutes. There is thus no evidence that either white or black players undercontributed playing time, in proportional terms. Notice also that the average winning percentage of both local teams and their opponents was only slightly over .500 , both ranging from .17 to .89 . This indicates that local stations televise a wide range of games involving both good and bad teams, and not only elite teams.

\section{DOES THE RACIAL COMPOSITION OF} A TEAM AFFECT NIELSEN RATINGS?

In estimating our model, we allow for the possibility of unobservable (and therefore omitted) team-specific factors that might systematically affect television viewing. These would include: local promotional advertising campaigns, or differential preferences across localities among viewers for watching basketball, versus other forms of entertainment. To control for such unobservable teamspecific factors, we estimate both fixed- and random effects models. Our fixed effect model is estimated with an incomplete set of regressors, excluding those regressors $(P O P$ ULATION, ALLSTARS, WHITEFANS, and $P R O T E A M S$ ) which are time-invariant, varying only across teams. ${ }^{12}$ Random effects models assume stochastic differences among cross-sectional observation units, and may be used to estimate a complete set of parameters even when some of the regressors are time-invariant. ${ }^{13}$

Heteroskedasticity may be present in the data, because Nielsen ratings for NBA games exhibit considerable variability across viewing markets, and viewing markets vary considerably in size. The presence of heteroskedasticity would result in consistent though inefficient parameter estimates and inconsistent estimates of the standard errors. Indeed, the results of a White test revealed heteroskedasticity at high levels of significance. ${ }^{14}$ Consequently, we estimated our models with a correction suggested by White (1980).

The results of a series of generalized least squares regressions on Nielsen ratings for local broadcasts of NBA basketball games are reported in Table 2. Table 2 reports the results of two sets of regressions, one using white players on the team rosters and the other using white playing time. In each case, race variables for the local and opposing teams are included separately. This is because preliminary $F$-tests rejected, at high levels of significance, pooling the race variables of the local and opposing teams, which indicated that white players on the local team had a different impact on viewing habits than white players on the opposing team.

12. The coefficients of time-invariant regressors are indeterminate in fixed effect models.

13. Random effects models can yield inconsistent parameter estimates when individual random effects are correlated with regressors included in the model. However, the results of an endogeneity test originally devised by Hausman and Taylor (1981) indicates no significant correlation between our random effects and model regressors.

14. See White (1980). 
TABLE 1

Definitions and Summary Statistics for the Explanatory Variables

\begin{tabular}{|c|c|c|c|c|}
\hline Variable & Mean & $\begin{array}{l}\text { Standard } \\
\text { Deviation }\end{array}$ & Minimum & Maximum \\
\hline WIN\%LOC & 0.53 & 0.19 & 0.17 & 0.89 \\
\hline$W I N \% O P P$ & 0.53 & 0.20 & 0.17 & 0.89 \\
\hline WHMINLOC & 0.17 & 0.11 & 0.00 & 0.48 \\
\hline WHMINOPP & 0.16 & 0.11 & 0.00 & 0.48 \\
\hline WHPLAYLOC & 2.40 & 1.31 & 0.00 & 5.00 \\
\hline WHPIAYOPP & 2.28 & 1.33 & 0.00 & 5.00 \\
\hline ALLSTARS & 1.00 & 0.86 & 0.00 & 3.00 \\
\hline WHITEFANS & 0.77 & 0.10 & 0.56 & 0.93 \\
\hline PRIMETIME & 0.63 & 0.49 & 0.00 & 1.00 \\
\hline LEADIN & 4.83 & 3.18 & 0.10 & 15.50 \\
\hline WEEKEND & 0.30 & 0.46 & 0.00 & 1.00 \\
\hline PROTEAMS & 2.06 & 1.64 & 0.00 & 6.00 \\
\hline HOUSEHOLDS & 1.91 & 1.39 & 0.64 & 6.71 \\
\hline Variable & \multicolumn{4}{|c|}{ Definitions } \\
\hline WIN $\% L O C$ & \multicolumn{4}{|c|}{ Winning percentage of local team } \\
\hline WIN\%OPP & \multicolumn{4}{|c|}{ Winning percentage of local team's opponent } \\
\hline WHMINLOC & \multicolumn{4}{|c|}{$\begin{array}{l}\text { Percentage of total team minutes played by white players for } \\
\text { the local team, per game }\end{array}$} \\
\hline WHMINOPP & \multicolumn{4}{|c|}{$\begin{array}{l}\text { Percentage of total team minutes played by white players for } \\
\text { the opposing team, per game }\end{array}$} \\
\hline WHPLAYLOC & \multicolumn{4}{|c|}{ Number of white players on local team's roster } \\
\hline WHPLAYOPP & \multicolumn{4}{|c|}{ Number of white players on opposing team's roster } \\
\hline ALLSTARS & \multicolumn{4}{|c|}{ Number of members of team selected to 1996 all-star game } \\
\hline WHITEFANS & \multicolumn{4}{|c|}{ Percentage of SMSA comprised of whites } \\
\hline PRIMETIME & \multicolumn{4}{|c|}{$\begin{array}{l}\text { Dummy variable }=1 \text { if game televised commencing } \\
\text { between } 6: 30 \mathrm{pm} \text { and } 9: 00 \mathrm{pm},=0 \text { otherwise }\end{array}$} \\
\hline LEADIN & \multicolumn{4}{|c|}{$\begin{array}{l}\text { Nielsen rating of the show televised immediately } \\
\text { prior to the game }\end{array}$} \\
\hline WEEKEND & \multicolumn{4}{|c|}{$\begin{array}{l}\text { Dummy variable }=1 \text { if game televised on } \\
\text { Saturday or Sunday, }=0 \text { otherwise }\end{array}$} \\
\hline HOUSEHOLDS & \multicolumn{4}{|c|}{ Total number of households in the SMSA, in millions } \\
\hline PROTEAMS & \multicolumn{4}{|c|}{$\begin{array}{l}\text { Number of professional sports franchises (basketball, football } \\
\text { baseball, and ice hockey) in the SMSA }\end{array}$} \\
\hline
\end{tabular}

Several results of Table 2 are worth noting. First, most of the coefficients of the race variables are positive and significant, some at extremely high levels. This indicates that whiter teams enjoyed significantly higher Nielsen ratings, after controlling for all other factors. Second, the coefficients on both WHPLAYLOC and WHMINLOC are larger than those of their opposing team counterparts, indicating that local white players exert a greater impact on viewing. This seems sensible: one might expect basketball fans on average to be more familiar with, and more likely to track the fortunes of, the white players on the local team. Finally, levels of significance and overall explanatory power are both higher in the regressions that include the number of white players rather than their minutes played. This suggests that simply having white players on the team may matter more than how much they actually play. This interpretation is supported by regressions that include both white players and white minutes, in which the players variables largely retain their significance, while the minutes variables do not.

What is the quantitative impact of fielding a whiter team? Focusing on the full random effects model, the estimated coefficient on WHPLAYLOC in column 3 implies that every additional white player on the local team increases the Nielsen rating by about 0.54 
TABLE 2

Determinants of Nielsen Ratings

\begin{tabular}{|c|c|c|c|c|c|c|}
\hline & GLS & $\begin{array}{l}\text { Fixed } \\
\text { Effects }\end{array}$ & $\begin{array}{c}\text { Random } \\
\text { Effects }\end{array}$ & GLS & $\begin{array}{l}\text { Fixed } \\
\text { Effects }\end{array}$ & $\begin{array}{c}\text { Random } \\
\text { Effects }\end{array}$ \\
\hline CONSTANT & $\begin{array}{l}-13.98^{* * *} \\
(-5.80)\end{array}$ & - & $\begin{array}{l}-16.95^{* *} \\
(-2.52)\end{array}$ & $\begin{array}{l}-12.23^{* * *} \\
(-4.86)\end{array}$ & - & $\begin{array}{l}-15.86^{* *} \\
(-2.25)\end{array}$ \\
\hline WINFLOC & $\begin{array}{l}10.60^{* * *} \\
(9.03)\end{array}$ & $\begin{array}{l}22.57^{* * *} \\
(3.42)\end{array}$ & $\begin{array}{l}17.64^{* * *} \\
(6.58)\end{array}$ & $\begin{array}{l}10.06^{* * *} \\
(8.96)\end{array}$ & $\begin{array}{l}22.59^{* * *} \\
(3.42)\end{array}$ & $\begin{array}{l}17.72^{* \ldots *} \\
(6.38)\end{array}$ \\
\hline WIN\%VIS & $\begin{array}{l}3.45^{* * *} \\
(3.57)\end{array}$ & $\begin{array}{l}2.79^{* * *} \\
(3.56)\end{array}$ & $\begin{array}{l}2.82^{* * *} \\
(6.23)\end{array}$ & $\begin{array}{l}3.93^{* * *} \\
(3.77)\end{array}$ & $\begin{array}{l}2.75 * * * \\
(3.50)\end{array}$ & $\begin{array}{l}2.79^{* * *} \\
(5.86)\end{array}$ \\
\hline PRIMETIME & $\begin{array}{c}-0.39 \\
(-0.87)\end{array}$ & $\begin{array}{c}0.16 \\
(0.53)\end{array}$ & $\begin{array}{c}0.16 \\
(0.76)\end{array}$ & $\begin{array}{c}-0.56 \\
(-1.18)\end{array}$ & $\begin{array}{c}0.14 \\
(0.48)\end{array}$ & $\begin{array}{c}0.14 \\
(0.66)\end{array}$ \\
\hline LEADIN & $\begin{array}{l}0.0018 \\
(1.10)\end{array}$ & $\begin{array}{l}0.00084 \\
(0.81)\end{array}$ & $\begin{array}{l}0.00084 \\
(0.82)\end{array}$ & $\begin{array}{l}0.0034^{*} \\
(1.87)\end{array}$ & $\begin{array}{l}0.0012 \\
(1.22)\end{array}$ & $\begin{array}{l}0.0012 \\
(1.17)\end{array}$ \\
\hline WEEKEND & $\begin{array}{c}0.39 \\
(0.92)\end{array}$ & $\begin{array}{l}0.87^{* \times *} \\
(3.11)\end{array}$ & $\begin{array}{l}0.86^{* * *} \\
(4.19)\end{array}$ & $\begin{array}{c}0.24 \\
(0.52)\end{array}$ & $\begin{array}{l}0.88^{* * *} \\
(3.08)\end{array}$ & $\begin{array}{l}0.86^{* * *} \\
(4.14)\end{array}$ \\
\hline HOUSEHOLDS & $\begin{array}{l}1.32^{* * *} \\
(6.31)\end{array}$ & - & $\begin{array}{c}1.08 \\
(1.41)\end{array}$ & $\begin{array}{l}1.15^{* * *} \\
(5.36)\end{array}$ & - & $\begin{array}{c}1.00 \\
(1.24)\end{array}$ \\
\hline PROTEAMS & $\begin{array}{l}-0.68^{* * *} \\
(-4.20)\end{array}$ & - & $\begin{array}{c}-0.68 \\
(-1.17)\end{array}$ & $\begin{array}{l}-0.50^{* * *} \\
(-3.13)\end{array}$ & $\overline{-}$ & $\begin{array}{c}-0.64 \\
(-1.05)\end{array}$ \\
\hline WHITEFANS & $\begin{array}{l}9.55^{* * *} \\
(3.95)\end{array}$ & - & $\begin{array}{l}12.03^{*} \\
(1.66)\end{array}$ & $\begin{array}{l}9.14^{* * *} \\
(3.65)\end{array}$ & - & $\begin{array}{l}11.50 \\
(1.50)\end{array}$ \\
\hline ALLSTARS & $\begin{array}{l}1.81^{* * *} \\
(5.64)\end{array}$ & - & $\begin{array}{c}0.89 \\
(1.00)\end{array}$ & $\begin{array}{l}1.80^{* * *} \\
(5.49)\end{array}$ & - & $\begin{array}{c}0.83 \\
(0.89)\end{array}$ \\
\hline WHPLAYLOC & $\begin{array}{l}1.19^{* * *} \\
(7.58)\end{array}$ & $\begin{array}{r}0.50^{*} \\
(1.83)\end{array}$ & $\begin{array}{l}0.54^{* * *} \\
(3.25)\end{array}$ & - & - & - \\
\hline WHPLAYOPP & $\begin{array}{l}0.30^{* *} \\
(2.29)\end{array}$ & $\begin{array}{c}0.21^{* *} \\
(2.34)\end{array}$ & $\begin{array}{l}0.21^{* * *} \\
(3.34)\end{array}$ & - & - & $\overline{-}$ \\
\hline WHMINLOC & - & - & - & $\begin{array}{l}11.79^{* * *} \\
(5.88)\end{array}$ & $\begin{array}{c}4.76 \\
(0.95)\end{array}$ & $\begin{array}{r}4.84^{*} \\
(1.89)\end{array}$ \\
\hline WHMINOPP & - & - & - & $\begin{array}{l}1.51 \\
(0.83)\end{array}$ & $\begin{array}{l}2.10^{* *} \\
(1.98)\end{array}$ & $\begin{array}{l}2.11^{* *} \\
(2.53)\end{array}$ \\
\hline$R^{2}$ & 0.629 & 0.852 & 0.558 & 0.595 & 0.850 & 0.526 \\
\hline
\end{tabular}

$N=258$.

${ }^{*}$ Significant at $90 \%$.

** Significant at $95 \%$.

${ }^{* * *}$ Significant at $99 \%$.

points, all else equal. This translates into anywhere from 3,500 to 36,200 additional households, depending on the size of the viewing market. The coefficient on WHMINLOC in column 6 implies that an additional twentyseven minutes of playing time contributed by local white players increases the Nielsen rating by about 0.545 points, or an effect comparable to having an extra white player on the roster. However, the lower level of significance of the coefficient on WHMIN$L O C$ indicates that this effect is subject to somewhat greater uncertainty.

All of the results on the remaining variables seem sensible. All else equal, Nielsen ratings are higher as the quality both of the local team and its opponent improves. An increase of 0.10 in the local team"s winning percentage (say, the difference between a team playing .500 ball and one playing .600 ball) increases its Nielsen ratings by nearly 1.8 points. Again depending on the size of the viewing market, this implies an increase of anywhere from 11,600 to 121,000 viewing households. The same increase in its opponent's winning percentage increases the Nielsen rating by about 0.28 points. The other highly significant result is that games played on weekends enjoy higher Nielsen ratings, by almost 0.9 points.

Though none of the other estimated coefficients in the random effects model are significant at standard levels, the results merit some discussion. We find, for example, that Nielsen ratings tend to be higher in larger cities with whiter fan bases and fewer alter- 
native pro franchises. These results, if not strongly corroborative, are at least consistent with the previous findings of Noll (1974) and Kahn and Sherer (1988) that whiter fan bases boost attendance at NBA games. On the other hand, there is little evidence that ratings are affected by whether or not games are broadcast during primetime hours, and only weak evidence of a small spillover effect of viewership from the previous televised show.

Perhaps surprisingly, we also find only weak evidence that the presence of allstar players on a team increases Nielsen ratings. This result should not, however, be taken to suggest that all-stars only marginally affect viewership, because the effect of allstars may be being captured by the team performance variable $W I N \% L O C$. Indeed, $W I N \% L O C$ and $A L L S T A R S$ are fairly highly correlated (correlation coefficient $=0.62$ ), and ALLSTARS becomes highly significant in regressions that exclude WIN\%LOC.

\section{WHAT IS THE COMMERCIAL ADVERTISING VALUE OF A WHITE PLAYER?}

Race-based decisions by viewers to watch games may have real financial consequences for NBA franchises, if commercial advertisers are willing to pay more for commercial slots aired during more popular shows. To the extent that viewers tune in more heavily to watch whiter teams, teams may be able to increase their commercial revenues by fielding more white players. NBA teams may well consider this possibility, since the NBA earns about as much from media revenues as it does from attendance at games. ${ }^{15}$ In this section, we report the results of an econometric analysis which quantifies the link between the size of viewing audiences and the prices paid for commercial slots during locally-televised NBA games. Combined with the findings of the preceding section, this exercise allows us to estimate how much white players bring to their teams in additional local TV advertising revenues.

The key data in this analysis are expenditures by companies for commercial slots

15. For example, in 1996, it was reported in Financial World that NBA gate receipts and media revenues were almost equal, each comprising a little over $40 \%$ of total league revenues. See Atre et al. $(1996,57)$. during locally televised NBA games. ${ }^{16}$ The source of these figures are Sport Facts: Local Market Monthly Sports Reports for January 1997, compiled by the Nielsen Media Research company. These reports contain information on the companies who advertised during a given game, including the amount of commercial air time purchased (the vast majority of which were 30-second slots), and the total expenditures by individual companies. ${ }^{17}$ Using this information, we constructed a team-level variable $A D V P M I N$, defined as advertising revenues per minute of commercial air time, in dollars. This variable varied considerably across teams, from a minimum of $\$ 1,473$ in Denver to a maximum of $\$ 26,962$ in New York City. The data did not permit construction of this variable at the level of the individual game.

Since the size of local markets differs considerably, a given Nielsen rating translates into quite different numbers of viewing households for different markets. Advertising companies are, of course, interested not so much in the percentage of the total audience that view their commercials but rather, the absolute size of that audience. Thus, their propensities to pay for commercial slots should depend on the number of viewing households, and not the Nielsen rating per se. For the analysis of this section, therefore, we used the variable HOUSEHOIDS to explain advertiser willingness to pay for commercials. In addition, to control for varying income levels across viewing markets, we created a variable PCINCOME, defined as per capita personal income, in thousands of dollars, for the metropolitan area where the game is broadcast. ${ }^{18}$ Controlling for income may be necessary if higher incomes increase the amount companies are willing to pay for slots, given any particular number of viewing households.

The results of an ordinary least squares regression of $A D V P M I N$ on HOUSEHOLDS

16. Under current arrangements, NBA teams receive $100 \%$ of all broadcast revenues for locally televised games, though they share broadcast revenues from most nationally televised games.

17. Nielsen Monitor-Plus Service, Nielsen TV, January 1997, various reports.

18. Statistical Abstract of the United States, 1996. p. 455 . 
and PCINCOME are as follows:

(1) ADVPMIN

$$
\begin{aligned}
& =-4418.82+37.70 \text { HOUSEHOLDS } \\
& (0.45) \quad(7.10) \\
& +243.16 \text { PCINCOME } \\
& (0.59)
\end{aligned}
$$

where the figures in parentheses are estimated $t$-ratios, and the $R^{2}$ equals $0.857 .^{19}$ The coefficient on HOUSEHOLDS is obviously highly significant, and indicates that every extra thousand viewing households increases local broadcast revenues by nearly $\$ 38$ per minute, or about $\$ 750$ per game, since there were on average about twenty minutes of commercials during a typical basketball game..$^{20}$

To calculate how much white players increase local commercial advertising revenues, recall that an extra white player increased viewing audiences by anywhere from 3,500 to 36,200 households, depending on the size of the local market. This implies that one white player will add about $\$ 2,600$ per game in revenues in the smallest viewing markets, and about $\$ 27,200$ per game in the largest markets. Under NBA rules, each team is allowed to televise locally a maximum of 41 regular-season games on non-cable channels. ${ }^{21}$ Table 3 reports the incremental local advertising revenue value of a white player in most NBA cities, assuming 41 games are televised. This value ranges from about $\$ 107,000$ in the smallest market, up to $\$ 1,114,000$ in the largest market, with a league-wide average of nearly $\$ 330,000$. This latter figure represented about $17 \%$ of the league-wide average salary during the 199697 NBA season.

These results provide a plausible explanation for the findings of several previous studies of salary determination in the NBA, which have documented the presence of a sizable, and statistically significant, salary gap

19. Both a White test and a Breusch-Pagan test for heteroskedasticity were negative. As expected, similar regressions using RATING explained much less of the variation in $A D V P M I N$, and the coefficients on $R A T I N G$ were barely significant at standard levels.

20. The coefficient on PCINCOME is highly insignificant, and regressions which omitted PCINCOME affected the coefficient on HHOLDS very little.

21. This figure constitutes one half of all regular season games. The rule does not cover cable channels, including the so-called superstation channels such as TN'T and TBS. See, for example, Deckert (1998).

\begin{tabular}{|c|c|c|}
\hline Team & Households & $\begin{array}{l}\text { Revenue } \\
\text { per Year }\end{array}$ \\
\hline & $(1,000 \mathrm{~s})$ & $(\$ 1,000)$ \\
\hline Atlanta & 1,625 & $\$ 269.8$ \\
\hline Boston & 2,150 & 357.0 \\
\hline Charlotte & 818 & 135.8 \\
\hline Chicago & 3,124 & 518.7 \\
\hline Cleveland & 1,461 & 242.6 \\
\hline Dallas & 1,849 & 307.0 \\
\hline Denver & 1,185 & 196.8 \\
\hline Detroit & 1,772 & 294.2 \\
\hline Golden State & 2,278 & 378.3 \\
\hline Houston & 1,595 & 264.8 \\
\hline Indiana & 939 & 155.9 \\
\hline I A Clippers & 4,942 & 820.6 \\
\hline LA lakers & 4,942 & 820.6 \\
\hline Miami & 1,363 & 226.3 \\
\hline Milwaukee & 787 & 130.7 \\
\hline Minnesota & 1,428 & 237.1 \\
\hline New Jersey & 6,711 & 1114.4 \\
\hline New York & 6,711 & 1114.4 \\
\hline Orlando & 1,022 & 169.7 \\
\hline Philadelphia & 2,654 & 440.7 \\
\hline Phoenix & 1,213 & 201.4 \\
\hline Portland & 953 & 158.2 \\
\hline Sacramento & 1,115 & 185.1 \\
\hline San Antonio & 642 & 106.6 \\
\hline Seattle & 1,492 & 247.7 \\
\hline Utah & 671 & 114.2 \\
\hline Washington & 1,908 & 316.8 \\
\hline Average & & 329.7 \\
\hline
\end{tabular}

TABLE 3

Annual Local Broadcast Revenue Value of a White Player on Various NBA Teams

between white and black players. Kahn and Sherer (1988), for example, estimated that black NBA players were paid about $20 \%$ less than comparable white players, adjusting for performance differentials. Using a similar methodology, Koch and Vander Hill (1988), found a smaller, and somewhat less significant, gap: nearly $12 \%$. A subsequent study by Brown, Spiro, and Keenan (1991) came up with an intermediate estimate of 14-16\%. Our finding that a white player on average brings in additional advertising revenues equivalent to $17 \%$ of the average NBA salary suggests that advertising revenue may largely account for the salary gap. We stress that this gap cannot be explained by differential effects of team racial composition on atten- 
dance at NBA games since, as we have seen, existing studies are mixed at best on whether such attendance effects exist.

Our finding that the advertising revenue value of whites increases with the size of the viewing market is consistent with another finding of Koch and Vander Hill (1988): that the salaries of white NBA players tend to increase more rapidly than those of black players as the population of the local metropolitan area increases. We find, however, a larger population effect. According to our estimates, in moving from the smallest NBA market (San Antonio) to the largest market (New York City), the advertising revenue gap between whites and blacks widens by nearly $52 \%$ of the league-wide salary average. This seems to be more than twice the effect found by Koch and Vander Hill. Some of this discrepancy may perhaps be explained by the fact that white players in the NBA have become more scarce in the intervening twelve years between our respective data sets, and as a result may now command even larger advertising premiums in large markets. In the 1984-85 season, whites comprised over one-quarter of all NBA players, whereas by 1996-97, they comprised slightly more than one-sixth. 22

\section{CONCLUSIONS}

The findings of this study indicate the existence of racially based patterns of fan viewing of locally televised NBA basketball games. All else equal, more fans tune in when there are more white players to watch, even when they are sitting on the bench. Indeed, the mere presence of white players on team rosters seems to have a more significant effect on Nielsen ratings than the number of minutes white players actually play. This finding can be interpreted as racial discrimination in the sense that viewing habits are indeed racebased. However, given the distinct minority status of white players in the NBA, it may also reflect identification with the underdog: a less pernicious motivation perhaps, but nevertheless one with real financial consequences for the players themselves.

Our findings speak to a puzzle that has appeared recently in the scholarly literature

22. See Koch and Vander Hill $(1988,83)$, for the for mer figure; the latter figure was calculated from our data set. on discrimination in sports. Specifically, our findings help reconcile the results of previous studies that find evidence that white NBA players are currently paid more than comparable black players yet find little evidence that whiter teams attract more fans to attend games. White players induce fans to tune in, not turn out: their additional marginal revenue product is on the air, not at the gate. Indeed, the emphasis in the literature on attendance at games may be somewhat misplaced, because many more fans watch or listen to broadcasts than actually attend games. $^{23}$

Future research will focus on the extent to which these results obtain more generally under other circumstances. We have already undertaken preliminary research that suggests that similar patterns of race-based viewing exist for NBA games televised on local cable networks. It would also be instructive to see whether similar results would obtain in nationally televised broadcasts of NBA games. Nationally televised games tend to involve better teams than do games broadcast locally. It is not obvious that we would observe the same race-based viewing patterns because viewer interest in such games, particularly ones with playoff implications, might be based more on game outcome and oncourt performance, than on factors such as race. On the other hand, discovering similar racially based patterns of viewing even for nationally televised playoff games would be particularly telling regarding the strength of fan preferences for watching white players. Furthermore, such patterns would be accompanied by even larger financial consequences, since companies pay considerably more for commercial slots for nationally televised NBA games. ${ }^{24}$

\section{REFERENCES}

Andersen, T., and S. J. La Croix. "Customer Racial Discrimination in Major League Baseball." Economic Inquiry, 29, 1991, 665-77.

Atre, T., et al. "The High-Stakes Game of Team Ownership." Financial World, 20 May 1996, 52-65.

Becker, G. M. The Economics of Discrimination. Chicago: University of Chicago Press, 1971.

23. See, for example, Noll and Zimbalist $(1997,57)$.

24. See, for example, Walker (1998, A14). 
Brown, E., R. Spiro, and D. Keenan. "Wage and Nonwage Discrimination in Professional Basketball: Do Fans Affect It?" American Joumal of Economics and Sociology, 50, 1991, 333-44.

Burdekin, R. C., and T. L. Idson. "Customer Preferences, Attendance, and the Racial Structure of Professional Basketball Teams." Applied Economics, 23, $1991,179-86$.

Deckert, T: R. "Casenotes: Multiple Characterizations for the Single Entity Argument?: The Seventh Circuit Throws an Airball in Chicago Professional Sports Limited Partnership v. National Basketball Association." Villanova Sports \& Entertainment Law Forum, 5(1), 1998, 73-98.

Gabriel, P. E., C. Johnson, and T. J. Stanton. "An Examination of Customer Racial Discrimination in the Market for Baseball Memorabilia."Journal of Business, 68(2), 1995, 215-30.

Greene, W. H. Econometric Analysis, 3rd ed. Upper Saddle River, NJ: Prentice-Hall, 1997.

Halberstam, D. The Breaks of the Game. New York: Alfred Knopf, 1981.

Hanssen, F. A., and T. Andersen. "Has Discrimination Lessened Over Time? A Test Using Baseball's AllStar Vote." Economic Inquiry, 37, 1999, 326-52.

Hausman, J. A., and W. E. Taylor. "Panel Data and Unobservable Individual Effects." Econometrica, 49, 1981, 1377-98.

Kahn, L. M. "Discrimination in Professional Sports: A Survey of the Literature." Industrial and Labor Relations Review, 44, 1991, 395-418.

Kahn, L. M., and P. D. Sherer. "Racial Differences in Professional Basketball Players' Compensation." Journal of Labor Economics, 6, 1988, 40-61.
Koch, J. V., and C. W. Vander Hill. "Is There Discrimination in the Black Man's Game?" Social Science Quarterly, 69, 1988, 83-94.

Nardinelli, C.. and C. Simon. "Customer Racial Discrimination in the Market for Memorabilia: The Case of Baseball." Quarterly Journal of Economics, 105, 1990, 575-95.

Nielsen Media Research. Web site (http:/Www. nielsenmedia.com).

. Nielsen Ratings: Station Index Local Market Sports Report, NBA Sport Reference Set, January and February 1997.

Sport Facts: Local Market Monthy Sports Report, various reports, January 1997.

Noll, R. G. "Attendance and Price Setting," in Government and the Sports Business, edited by R. Noll. Washington, DC: Brookings, 1974, 115-57.

Noll, R. G., and A. Zimbalist, eds. Sports, Jobs, and Taxes: The Economic Impact of Sports Teams and Stadiums. Washington, DC: Brookings, 1997.

Schollaert, P. T., and D. H. Smith. "Team Racial Composition and Sports Attendance." Sociological Quarterly, 28, 1987, 71-87.

Sporting News. Official NBA Register, 1996-97 edition. New York: Sporting News, 1996.

United States. Statistical Abstract of the United States, 1996. Washington, DC: Government Printing Office, 1996.

Walker, S. "NBA Sponsors May Be Slow to Rebound," Wall Street Journal, 7 January 1999, sec. A, p. 14.

White, H. "A Heteroscedasticity-Consistent Covariance Matrix Estimator and a Direct Test for Heteroscedasticity." Econometrica, 48, 1980, 817-38. 


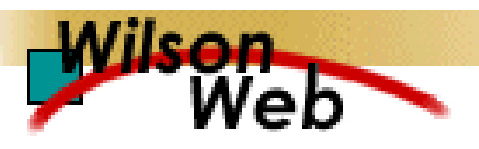

\section{COPYRIGHT INFORMATION}

TITLE: Racial discrimination in professional basketball: evidence from the Nielsen ratings

SOURCE: Economic Inquiry 39 no4 O 2001

WN: 0127403492009

The magazine publisher is the copyright holder of this article and it is reproduced with permission. Further reproduction of this article in violation of the copyright is prohibited. To contact the publisher: http:/www.weainternational.org.

Copyright 1982-2001 The H.W. Wilson Company. All rights reserved. 